\title{
WATER STORAGE INDEX ESTIMATION USING GEOGRAPHIC INFORMATION SYSTEM
}

\section{E stimasi Indeks Penampungan Air menggunakan Sistem Informasi Geografis}

\author{
Agus Wuryanta and Ugro Hari Murtiono
}

Researcher on Forestry Technology Research Institute on Watershed Management e-mail: agus_july1065@yahoo.com

\begin{abstract}
ABST RACT
Thestudy aims to estimate water starageindex (IPA) of six subvatesheed (Panjang Rengss Leej, Galeh, Parat, and Sraten) in thecadment aree of Rawaperinglakeby using Geogaphic Infomation System Water staraceindex can becalaulated fromaverage discharce $(\mathrm{m} 3)$ devided by water requirenett (m3) for each land cover/ land use Landuse information is ddtained from Indonesian Topographic Map scale of 1:25.000 as updated by using SPOT image (2006), while suface water availability data was ddained from theministry of pubic works Theresults indicate that 1) IPA of Panjang Subvatershed was cateeg nized as good condition with an index value of 1,49; 2)IPA of Rencas and Leej sub watersheed were categrized as modarate condition with index value 0,76 and 0,55; 3) IPA of Galdh, Parat, and Sraten sub watesheels was categonized as bad with index value of 0,3, 0,15, and 0,33, this watesheed need to be improved espeially an effective vater resarces plan, allocating and distributing of water according to priarity establishment.
\end{abstract}

Keywords: water storage index/ IPA, sub watershed health, G eographic Information Syatem (GIS)

\section{ABST RAK}

Penditian ini betujuan untuk mempekirakan Indks Penampungan Air (IPA) dan enamsub DAS (Panjang Reras, Legy, Galeh, Parat, and Sraten) di DAS Ravaperingmengunakan SistemInfarmas Geogatis(SIG). PehituncanIPA didasarkan pada reata discharge(m̉) dibag denganjumlahkebutuhan air (m3) untuk masingmasing penggumaan lahan. Informasi pengunaan lahan diperdeh dan RBI skala 2 : 25.000 yang dupdate dengan atra SPOT (2006). Sementara ketesediaan air pemikaan diperdeh dari data kementrian PU. Hasil penditian menunjukkan bahma berdasarkan perhitungan IPA: 1) SubDAS Panjangtemastk kategri baik danganindkss 1,49. 2) SubDAS Rengas dan Leg் masuk dalamkateegri sedang dengan indkss 0,76 dan 0,55. 3) Sub DAS Galeh Parat, dan Sraten temastk dalamkategri bunk denganindkss 0,3; 0,15; dan 0,3 shingga pelu ditingkatkankhususnya dalam hal perenamaan SDA, aldksi, dan distribusi tekkait dengan pricitas yang ditertukan

Kata kunci: IPA, kesehatan DAS, SIG 


\section{INTRODUCTION}

Watershed managements play an important role in the future in many developing countries where watershed management concepts and the supporting skills have not been well developed. Population growth and increasing demands for natural resources in these countries have exerted severe impacts on watersheds which require careful integrated watershed planning (Low.,1990). Damage to watershed areas can result to a variety of disaster suchs as siltation of rivers, canals, dams, and flood. The number of watersheds that require priority of management were continuously increase from 22 watersheds in 1984 to 39 and 62 watersheds in 1992 and 1998, respectively. Currently, there are about 108 watersheds need management priority. D ecreasing of watershed function was because of exploitatively natural resource utilizations which was higher than its carrying capacity and capability (Paimin, et al. 2012).

Lake of Rawapening is one of the priority control of environmental issues associated with high sedimentation, resulted from high soil erosion on the catchment area. Sedimentation in Lake of Rawapening is tend to be increased from 133,75 $\mathrm{m}^{3}$ in 1993 to $149,22 \mathrm{~m}^{3}$ in 2003 . However, the capacity of water of Lake of Rawapening decreased about 16 million $\mathrm{m} 3$ over a periode of 28 years (1976 untill 2004) from 65 million $\mathrm{m} 3$ to 49 million m3 (kompas, 2009). If no efforts to save, the existence of the natural lake is threatened and expected in the year of 2012 will turn into mainland. Catchment area of Lake of Rawapening is located in the upper of Tuntang watershed.

Upper watershed ecosystem is an importants part because it has a protective function of water to all part of the watershed. Land management activities in the upper watershed such as convertion of for- est land, landuse not in accordance with the carrying capacity of land results land resources degradation. The research objective was to estimate water storage index (IPA) of six sub watersheds (Panjang, Rengas, Legi, Galeh, Parat, and Sraten) in the cachment area of lake of Rawapening by using G eographic Information System.

\section{RESEARCH METHOD}

This research was located in catchment area of Lake of Rawapening. Administratively, most of the research area is in Semarang District Central Java Province and is geographically located at coordinate $110^{\circ} 17^{\prime}$ east longitude - $110^{\circ} 30^{\prime}$ east longitude dan $7^{\circ} 5^{\prime}$ south latitude - $7^{\circ} 25^{\prime}$ south latitude. Research location is illustrated at Figure 1.

The materials and tools used in this research were: (1) Base map: Indonesia topographic map scale 1:25.000 (digital format), Administrative map, Contour map, dan Road and river network map. (2) Sattelite image: Digital SPOT image recorded 2006. (3) Tools: Software ArcView 3.2, Erdas Imagine 8.4, computer, dan Global Positioning System (G PS).

The research was conducted with the following steps: (1) D elineating sub watershed using contur and river network map, (2) Land cover/ land use information obtained from IndonesiaTopographic Map (RBI) scale of 1:25.000 (digital format), updated by using SPOT image (2006 recorded), field check conducted in 2011, (3) Calculating area of land cover/ land use, (4) Average discharge annualy (from 2000 to 2009) was obtained from Semarang D istrict D epartment of Public Works for six rivers, (5) Calculating of water requirement for each land use/ land cover (base on D umairi, 1992) presented at appendix 1. (6) Calculating of water storage index for six sub watersheds. 


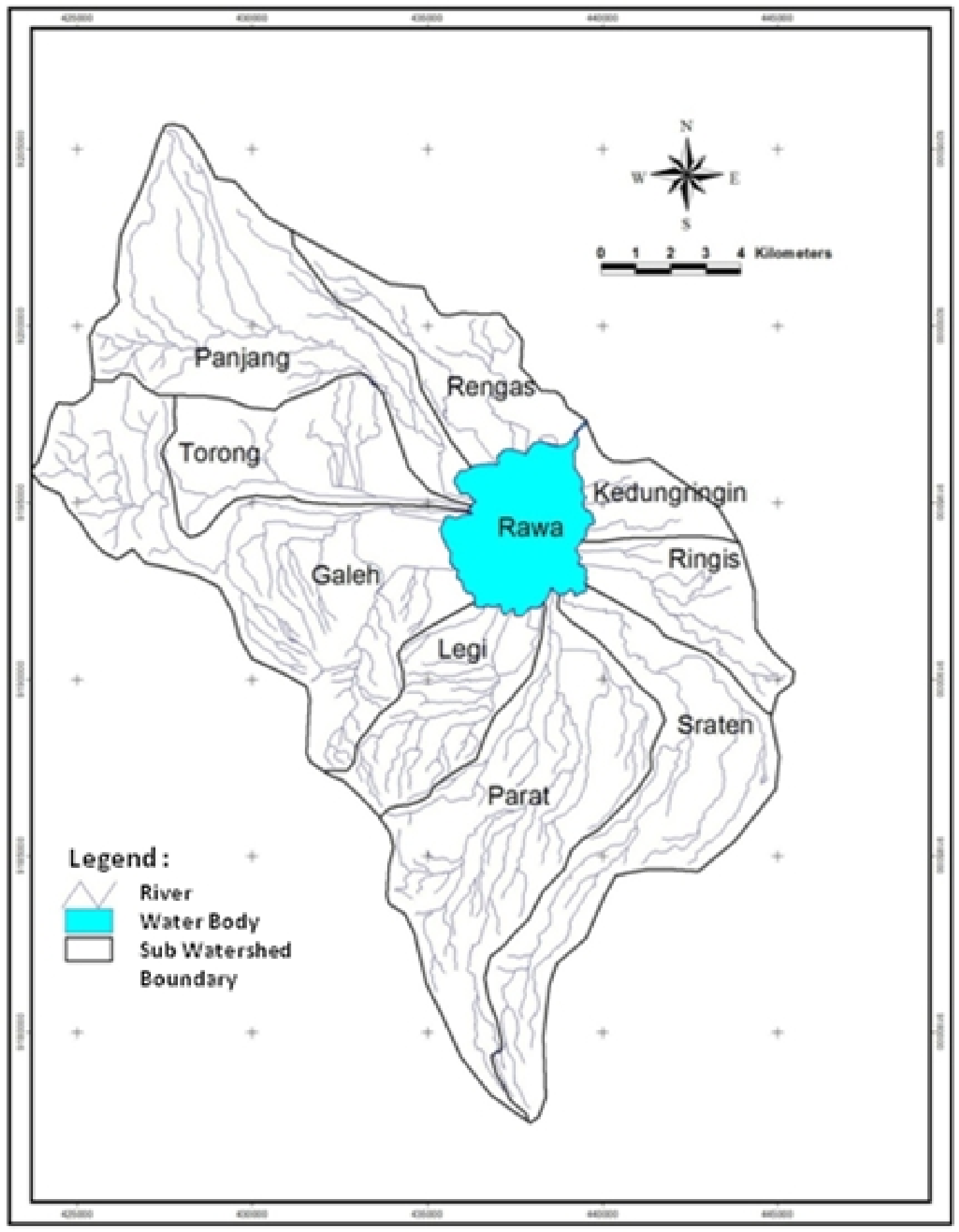

Figure 1. Map of Catchment Area of Lake of Rawapening 


\section{RESULT AND DISCUSSION}

Land cover/ land use information is one of the important parameter in watershed management planning. Therefore, accurate and up todate information of land cover/ landuse is necessary to conduct watershed management activity. Information of land cover/ land use of catchment area of Lake of Rawapening was obtained from Indonesia Topographic Map scale of 1:25.000 (digital format), and has been up dated by using SPOT 2 image 2006 recorded and field check was conducted in 2011. Land cover/ land use type in the study area can be devided into 12 types namely rare forest, rare private forest, dense private forest, dense forest, settlement, mix settlement with dry field, estate, dryland farming, irrigated land (paddy field), shrub, dry land/ vegetable crop, and water body. The area of land use/ land cover of each sub watershed was presented at table 1 .

For water requirement calculation, the land cover/ land use is reclasified into five main land cover/ land use types namely forest, dryland farming, irrigated land/ paddy field, dryland/ vegetables crop, and settlement. The area of the land cover/ land use (after reclassification) was presented at table 2 . While water requirement of each land cover/ land use of each sub watershed was presented at table 3.

Based on table 2. Forest (consisting of rare forest, rare private forest, dense private forest and dense forest) occupies the largest area $(12.120,55 \mathrm{ha})$. The largest forest area occured at $\mathrm{G}$ aleh sub watershed (5.043,82 ha). While, settlement (consisting of settlement and mix settlement and dryland) occupies the smallest area $(2.213,59)$.

Average discharge annualy of six rivers (from 2000 to 2009) was obtained from Department of Public Works of Semarang
District as presented at table 4 . Value of water requirement and average discharge was used to calculate water storage index (IPA). Average discharge indicates water availibility of each sub watershed. IPA can be calculated by using a formula :

$$
\text { IPA }=\frac{\text { A verage discharge }\left(\mathrm{m}^{3}\right)}{\text { Water requirement }\left(\mathrm{m}^{3}\right)}
$$

Water storage index (IPA) of each sub watershed in the research area was calculated and as presented at table 5 . Value of water storage index (IPA) can be used to evaluate sub watershed health. Classification of IPA is presented as:

1. IPA $<0,5$ (bad)

2. IPA $0,5-0,9$ (moderate)

3. IPA $>0,9$ (good)

Panjang Subwatershed was categorized as good condition with an index value (IPA) of 1,49 as indicates that water availability of the sub watershed is bigger than water requirement. Rengas and Legi sub watershed has an index value (IPA) of 0,76 and 0,55 was categorized as moderate condition. While Galeh, Parat, and Sraten sub watershed was categorized as bad condition with an IPA value of $0,33,0,15$, and 0,33 . Sub watershed wich is having bad condition needs improvement especially an effective water resources plan, allocating and distributing of water according to priority establishment.

\section{CONCLUTION}

1. Panjang Subwatershed was categorized as good condition with an index value (IPA) of 1,49 as indicates that water availability of the sub watershed is bigger than water requirement. 


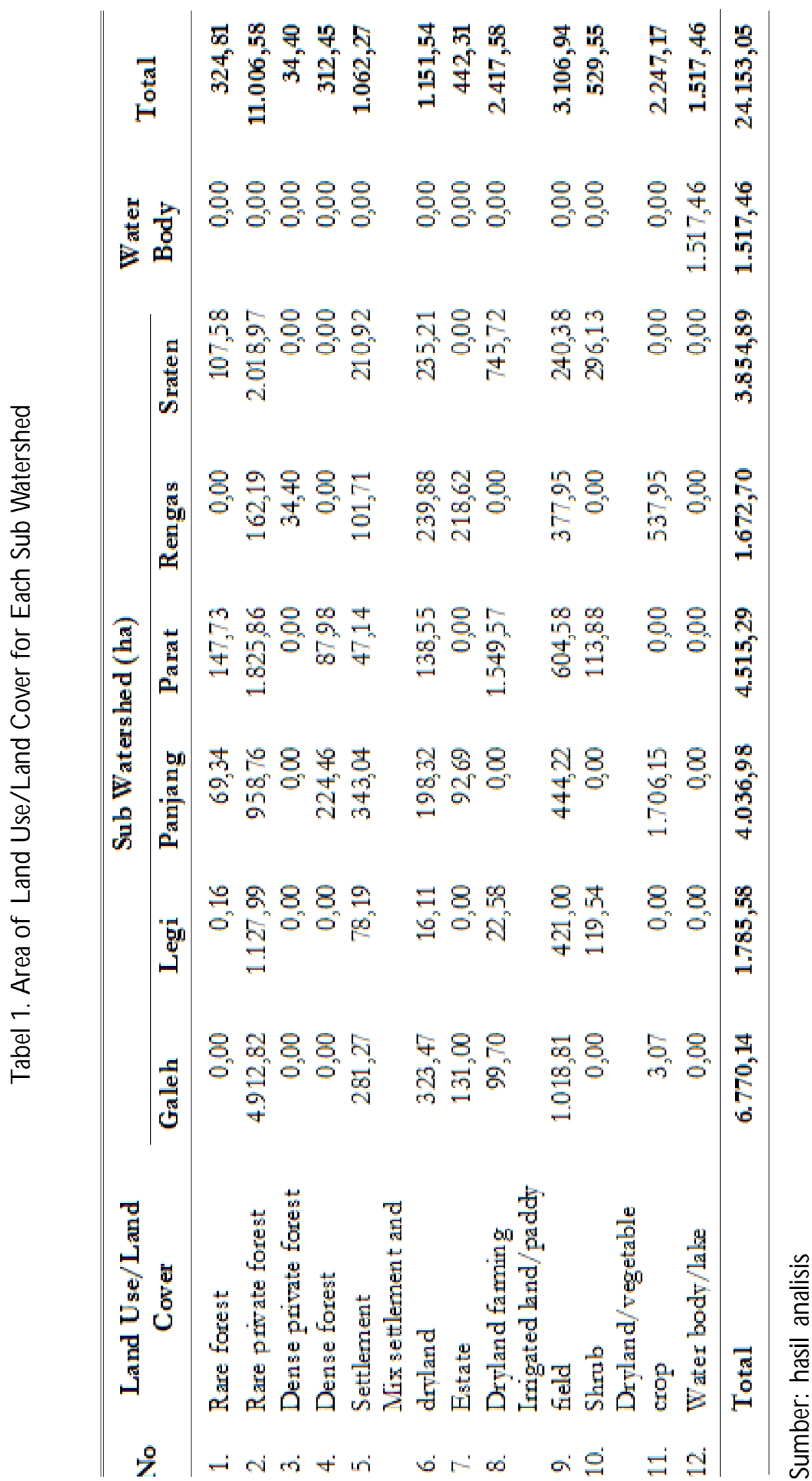



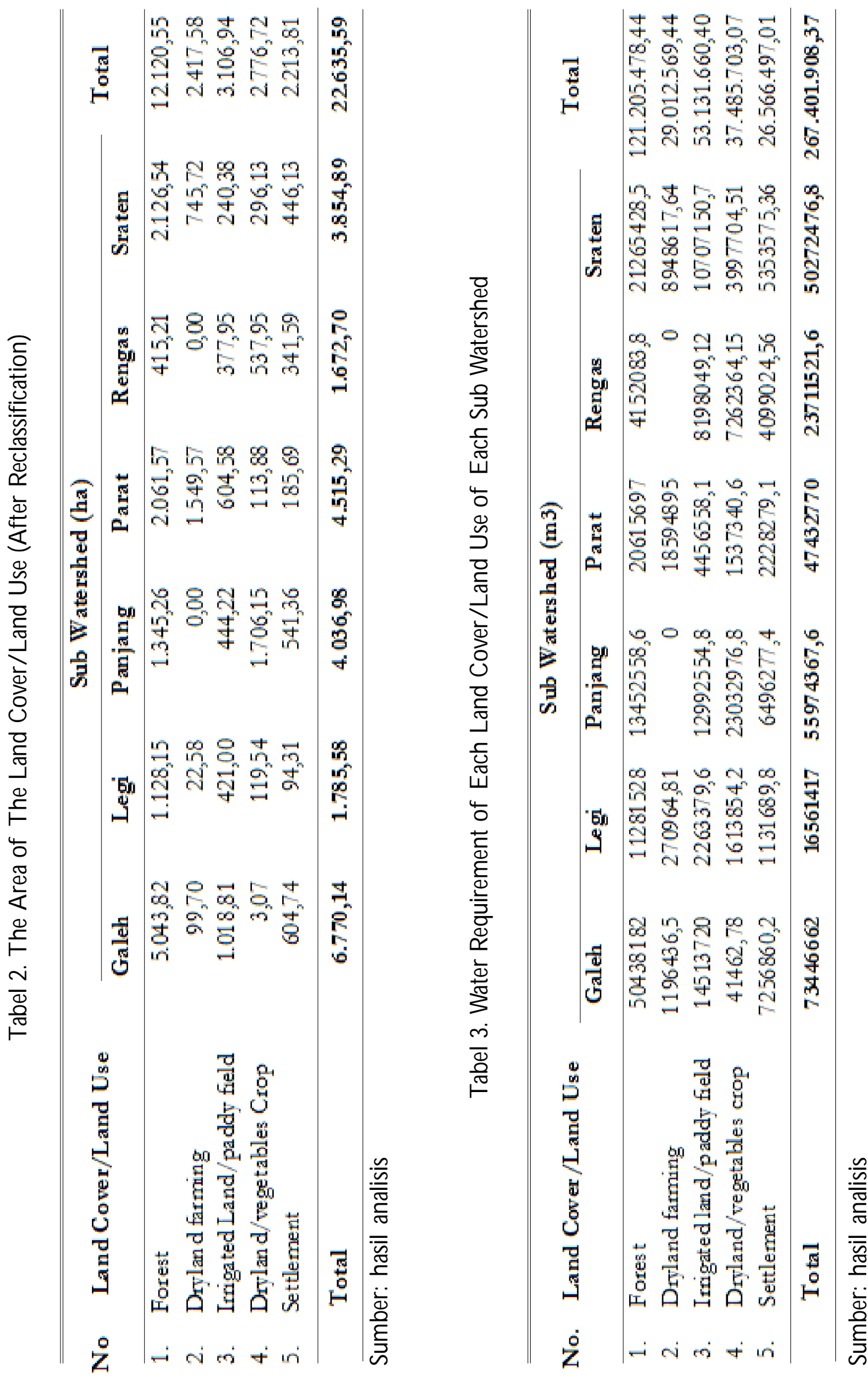

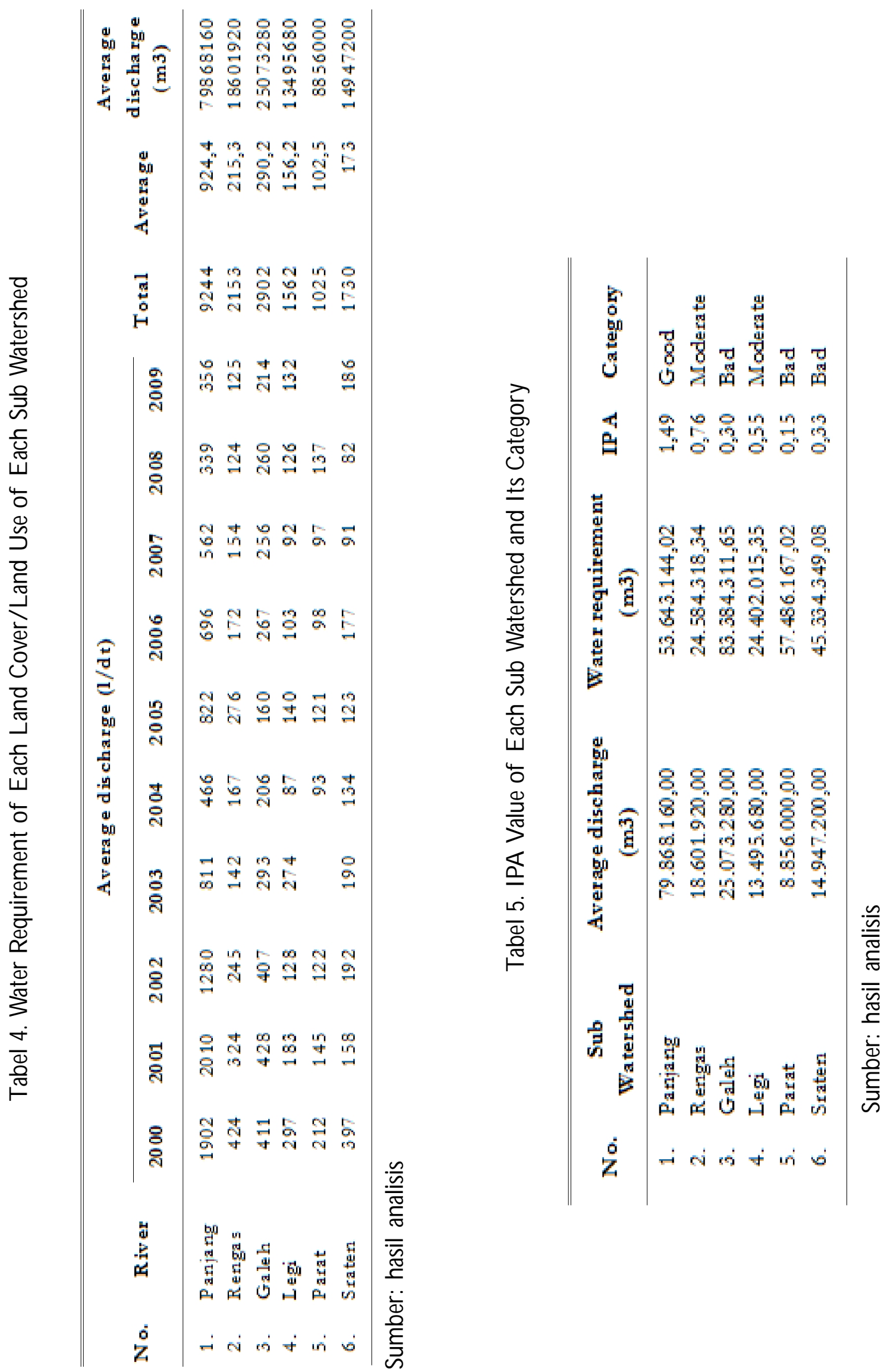

Water Storage Index ... (Wuryanta and Murtiono) 
2. Rengas and Legi sub watershed has an index value (IPA) of 0,76 and 0,55 was categorized as moderate condition
3. G aleh, Parat, and Sraten sub watershed was categorized as bad condition with an IPA value of $0,33,0,15$, and 0,33

\section{DAFTAR PUSTAKA}

Kompas 2009. Rawa Pening Kampungitu Beubah Mejadi Rava. 10 Juni 2009.

D umairi. 1992. Ekononika Sumber daya Air. Pengantar ke Hidronamika, BPFE. Y ogyakarta

Low Sim K wai. 1990. Manual onWateshedReserch ASEAN-USWATERSHED PROJECT. College, Laguna Philippines 4031. 1990.

Paimin, Ugro H Murtiono, and Agus Wuryanta. 2012. Assement of FloodVulneability at The Upper Tuntang Sub Wateshed Cetral Java Proince 